\title{
The importance of constructivism in the teaching social and humanitarian disciplines
}

\author{
Leyla B. Omarova ${ }^{1 *}$, Diana Z. Muzashvili ${ }^{2}$, Irina $G$. Prokhorova ${ }^{3}$, and Ayub Sevdim ogly \\ Kerimov $^{4}$ \\ ${ }^{1}$ Financial University, Department of Humanities, Moscow, Russia \\ ${ }^{2}$ Financial University, Department of Psychology and Human Capital Development, Moscow, Russia \\ ${ }^{3}$ Financial University, Department of Sociology, Moscow, Russia \\ ${ }^{4}$ Azerbaijan Technical University, Department of Social Sciences, Baku, Azerbaijan
}

\begin{abstract}
The relevance of the topic is dictated by the inconsistency of the contemporary education system. On the one hand, the pedagogical community defends traditional teaching methods. On the other hand, there is a need to implement new methods that meet the current generation's interests and worldview. The purpose of the present study is to identify the possibility of using constructivist elements in pedagogical activity, which are elements of the subject-to-subject paradigm of education. The need to implement elements of constructivism in educational activities is determined by the peculiarities of contemporary social life, in which the main role in the formation of everyday reality is played by virtual digital reality and information technologies. The conducted analysis was based on the studies directly related to the field of education and pedagogy, as well as works on philosophy, sociology, and psychology that explore the problems of education in present-day developments. The analysis of the contemporary educational system and the concept of constructivism in education are presented based on the conducted work. Study materials can be used to analyze and solve debatable issues of contemporary education and pedagogy.
\end{abstract}

Keywords: education, constructivism, creativity, model, pedagogy.

\section{Introduction}

The history of Russian education of the 20th-21st centuries is full of reforms. Large-scale transformations of the 90 s of the 20th century in the sphere of politics, economy, and social life have led to certain educational system changes, which had an ambiguous result [1-3].

Since 2003, Russia has been a participant in the Bologna Process, which implies a multilevel system of higher education characterized by both pros and cons. The advantages of such a system include the Russian students' mobility and the increasing demand in the international market. Simultaneously, the disadvantage is the insufficient development of academic curricula characterized by the duplication or logical inclusion of certain disciplines in different level curricula.

\footnotetext{
${ }^{*}$ Corresponding author: lomarova@,fa.ru
} 
"Formally, the contemporary Russian education system corresponds to the classical model, which originates in the pedagogical schools of Europe at the beginning of the 19th century. This traditional model assumes that the student, based on school knowledge, will move on to independent assimilation of knowledge, values, and skills of a higher order than previously mastered, definitely not without the assistance of a teacher" [4: 24]. However, considering this model from the inside, one can state that this is subject-to-object education, which is informative and reproductive learning, where the student reproduces ready-made knowledge, dictated by the teacher. According to the authors, this teaching approach gives neither ground for creativity nor develops the ability to think independently. In the presentation "Active teaching methods at universities", professor Nguyen Hoang Tien states: "If there is no independent thinking, then there can be no creativity, while the creative element is necessary for developing intelligence in general" [5].

While the subject-to-object method is more or less suitable for the $\mathrm{STEM}^{\dagger}$ subjects, then the learning process associated with the humanities, and in particular, with philosophical disciplines, cannot and should not be subject-to-object: the student is not just an object of information perception but a cognizing subject, a unique personality with a certain development trajectory.

\subsection{Hypothesis}

Present-day developments, associated with powerful scientific and technological progress, the constant increase in the volume of information flows, and the transformation of the nature of relations between generations determine the implementation of education concepts and models based on the ideas of constructivism that would meet these transformations.

The constructivist and projective approaches are the basis of social and humanitarian knowledge. They aim at a positive transformation of human consciousness and are distinguished by focusing on communication with the audience, response, and the formation of a special worldview and world feeling.

\section{Methods}

The main methods used in the study (dialectical, structural, and functional) are systematic, which allowed showing more fully the influence of constructivism on the results of educational activities. The personal-activity approach to the analysis of constructivism allowed studying comprehensively the model of education, which assumed a subject-tosubject approach to the cognition process.

\section{Results}

The "zone of applicability" of constructivism includes a research perspective of education.

The constructive element in the teaching of social and humanitarian disciplines in modern reality with the prefix "post" has three trends of application.

The first trend is that when forming the categorical framework of students, the introduction of terms and images is carried out not only through familiarity with models and methods but also through a consistent critical analysis of intellectual constructions.

The second trend is that the educational process should be based on forming students' ability for continuous self-reflection and the disclosure of the basic epistemological potential, according to cultural, physical, and psychological characteristics.

\footnotetext{
$\dagger$ Science, Technology, Engineering and Mathematics
} 
The third trend concerns the inevitable increase in educational eclecticism. According to the comparative method, which is used in most social and humanitarian scientific research, eclecticism can become a construct of a new vision, enriching science or revealing elements and interesting facets for students. At that, developed creative thinking and innovation benefit both students and teachers [6:2589].

The goal of education is not only to make the student literate but also to develop his rational thinking, ability to learn, and self-sufficiency.

\section{Discussion}

The ideas of constructivism are studied and analyzed at an interdisciplinary level. Therefore, both in foreign and domestic science, these ideas are the focus of philosophers, historians, psychologists, and specialists in pedagogy.

The task of modern education is not only to adapt the student to the surrounding world but also to explain that the cognizing subject should act as an equal participant in the changes in present-day realities.

In the Russian pedagogical science, the issues of the influence of the constructive approach in education on its quality are in the spotlight of Russian scientists, such as L.S. Vygotsky, P.Ya. Galperin, E.N. Knyazeva, S.P. Kurdyumov, V.A. Lektorsky, as well as practice-oriented works of N.P. Shatalova, and F.D. Bunyatova.

In the theories of foreign authors, such as M.R. Matthews [7], D.D. Pratt [8], and V. Richardson [9], the constructive approach in education is considered from different perspectives proceeding from different assessments of the constructive approach in education. Western scientists are skeptical about the constructive approach in education but recognize that this approach is one of the most effective approaches, coming from the very nature of a person who strives for an independent assessment of being, since "all knowledge is necessarily the product of their own cognitive actions" [7: 304]. Considering constructivism from both the ontological and epistemological viewpoints, it can be revealed that constructivism is a mandatory element of knowledge in general. Therefore, it is necessary to redefine education to include more critical thinking, adopting constructivist pedagogy [10: 7]. The articles collection "Innovative Teaching Methods" published in 2020 by the researchers of Maria Curie-Skłodowska University focuses on the fact that education should encompass methods that stimulate creativity [11: 8].

Constructivism in education should be integrated with epistemology and pedagogy. The main purpose of such a system is to develop a person in his life roles and learning how to function in society through the acquisition of new experiences.

Constructivism in teaching assumes that the teacher will lead the process of a student's learning, directing him to a particular problem. While at the initial stage the teacher is responsible for the knowledge acquired by the student, the use of constructivist elements implies a gradual transition of this responsibility to the student. Responsibility should be conscious and include the student's cognitive activity [1:275].

Developing same ideas, D.D. Pratt writes about the constructivist model of education as a vector of student's development, whose main goal is developing increasingly complex forms of thinking that would contribute to solving complicated problems in professional activity [8: 32].

\section{Conclusion}

Constructivism is primarily a dialogue between a teacher and a student, where both bear conscious responsibility for the result of learning and cognition. For example, according to 
the theory of reflection, the main theory of epistemology, the results of cognition should be relatively adequate to their original source; however, such a copying theory of truth limits the capabilities of creative thinking, driving the cognition process into a narrow framework. Constructivism, oppositely, destroys this framework, proving that the cognizing subject not only copies but also updates the theory, including elements previously unnoticed. This is precisely the value of constructivism as a necessary element of thought and action of a cognizing subject who independently determines the methods and approaches, goals, and objectives of the research, directing it into certain areas to obtain new and valuable results [12: 37]. Constructivism creates the ground for constant and active reworking and reinterpretation of the reality of the two subjects of education. If nothing happens in the teaching process not only with the student but also with the teacher, then such education is not always productive.

The inclusion of the constructivist element in education and pedagogy is similar to the synergetic methodology of the German professor H. Haken, who has argued that not everyone can create in this reality because reality cannot be infinitely plastic for human actions since it is limited by the internal laws of being and nature. The scientific status of the contemporary social sciences and humanities also shows that it is possible to construct only what is consistent with the objective laws, the axioms of these sciences. "Any cognitive activity of the subject and any life experience are a construct (cognitive structure)" [13: 7; 14].

At the present stage, for using social and humanities disciplines in education, the special role is played by cognitive constructivism, which implies willingness to self-development of the student and teacher, as well as their active learning [15]. This method promotes the transition from teacher-centered learning to student-centered learning [2: 38]. The constructivist element in teaching of social and humanitarian disciplines creates open communicative and dialogic meanings. Such an approach is not only methodically justified but also forms students' skills of innovative and analytical thinking, which in turn is a necessary element for successful professional activity.

\section{References}

1. V.A. Lektorskiy et al., Voprosy Filofiii [Questions of Philosophy], 3, 3-37 (2008)

2. B. Birgili, Z. Kiziltepe, F. N. Seggie. World Studies in Education, 17(2), 37-52 (2016)

3. N.G. Bondarenko, G.I. Lukyanov, T.M. Makhamatov, L.I. Egorova, T.I. Avdeeva, E.N. Belyanova, Journal of Advanced Research in Dynamical and Control Systems, 12.S1, 386-393 (2020)

4. M.I. Bilalov,. Bulletin of the Financial University, 1(13), 24-33 (2014)

5. N.H. Tien, Active teaching methods at universities, in Proceedings of University Scientific Conference on "Improving the Curriculum of IT Curriculum in Accordance with the CDIO Approach", 17 September 2018, Tien Giang, Vietnam (2018). Accessed on: December 10, 2020. [Online]. Available:

https://www.researchgate.net/publication/338924933_Active_Teaching_Methods_at_U niversities

6. M. Vijayalakshmi, Journal of Applied Science and Computations, VI. I, 2588-2596 (2019)

7. M.R. Matthews, Old wine in new bottles: A problem with constructivisit epistemology, in Philosophy of education yearbook, proceedings of the forty-eighth annual meeting of philosophy of education society, 303-311(US Philosophy of Education Society, Urbana (IL.), 1992) 
8. D.D. Pratt, New Directions for Adult and Continuing Education, 93, 5-16 (2002). https://doi.org/10.1002/ace.45

9. V. Richardson, Teachers College Record, 105(9), 1623-1640 (2003). https://doi.org/10.1046/j.1467-9620.2003.00303.x

10. V. Dagar, A. Yadav, Arts and Social Sciences Journal, 7, 200 (2016)

11. L. Pokrzycka, Innovative teaching methods (Maria Curie-Skłodowska University Press, Lublin, 2020)

12. E.V. Zorina, Konstruktivnyy element v prepodavanii filosofii. Problemy prepodavaniya filosofii pri dvukhurovnevoy sisteme obrazovaniya Bakalavr-magistr [A constructive element in teaching philosophy. Problems of teaching philosophy in a two-tier education system Bachelor-Master] (Moscow, 2010)

13. V.O. Bogdanova, Konstruktivistskoye filosofstvovaniye: osobennosti i smysly [Constructivist philosophizing: features and meanings] (Publishing house of the Chelyabinsk State Pedagogical University, Chelyabinsk, 2015)

14. J. Van de Pol, M. Volman, Education Psychology Review, 22(3), 271-295 (2010)

15. T.M. Makhamatov, T.T. Makhamatov, S.T. Makhamatova, Lecture Notes in Networks and Systems, 129, 816-825 (2020) 